\title{
CREATING SENSATION OF LEARNING IN CLASSROOM: USING 'GATHER TOWN' PLATFORM VIDEO GAME-STYLE FOR VIRTUAL CLASSROOM
}

\author{
Tira Nur Fitria \\ Institut Teknologi Bisnis AAS Indonesia \\ tiranurfitria@gmail.com
}

\begin{abstract}
Virtual classes have now become commonplace during the COVID-19 pandemic. As time goes by, applications for virtual meetings continue to appear, one of which is Gather Town, which is now widely used and is a tight competitor to Zoom Meeting and Google Meet. Gather Town is a virtual meeting platform designed like a video game. This research is to implement the use of the 'Gather Town' game platform and to find out the student's perception during the implementation and simulation of Gather Town application as an alternative platform in creating a sensation of English Language Learning (ELL) in the real classroom through virtual class during the pandemic COVID-19. This study uses descriptive qualitative research. The result analysis from observation and interview show that Gather Town has graphics similar to the Harvest Moon game, where students can play one character and can write their name on the top so that the lecturer can see which students are present. The room is designed similar to a classroom, where the lecturer's desk is at the front of the classroom. The virtual classroom also has chairs that are neatly lined up like classrooms in the real world. Then when doing group assignments, the student characters will gather at the same table as in a real classroom. They also carry out group work activities as if they were in the classroom. Each group sat in a circle and discussed with one another. The current game may be an alternative design in a virtual classroom.
\end{abstract}

Keywords: classroom, virtual class, Gather Town, video game-style, game platform

\begin{abstract}
Abstrak: Kelas virtual kini menjadi hal biasa selama pandemi COVID-19. Seiring berjalannya waktu, aplikasi untuk virtual meeting terus bermunculan, salah satunya adalah Gather Town yang kini banyak digunakan dan menjadi pesaing ketat Zoom Meeting dan Google Meet. Gather Town adalah platform pertemuan virtual yang dirancang seperti gim video. Penelitian ini bertujuan untuk mensimulasikan penggunaan platform game 'Gather Town' dan mengetahui persepsi siswa selama simulasi aplikasi Gather Town sebagai platform alternatif dalam menciptakan sensasi Pembelajaran Bahasa Inggris di kelas nyata melalui virtual. kelas selama pandemi COVID-19. Penelitian ini merupakan penelitian kualitatif deskriptif. Hasil analisis dari observasi dan wawancara menunjukkan bahwa Gather Town memiliki grafik yang mirip dengan game Harvest Moon, dimana mahasiswa dapat memainkan satu karakter dan dapat menuliskan namanya di bagian atas sehingga dosen dapat melihat mahasiswa mana yang hadir. Tidak hanya itu, ruangannya didesain mirip dengan ruang kelas, dimana meja dosen berada di bagian depan kelas. Ruang kelas virtual juga memiliki kursi yang berjejer rapi seperti ruang kelas di dunia nyata. Kemudian saat mengerjakan tugas kelompok, karakter siswa akan berkumpul di meja yang sama seperti di ruang kelas yang sebenarnya. Mereka juga melakukan kegiatan kerja kelompok seolah-olah berada di dalam kelas. Setiap kelompok duduk melingkar dan berdiskusi satu sama lain. Game saat ini dapat menjadi alternatif desain di kelas virtual.
\end{abstract}

Kata kunci: kelas, kelas virtual, Gather Town, gaya video game, platform game 


\section{INTRODUCTION}

The 2020 Covid-19 pandemic is a challenging case in point (Bergan et al., 2021, p. 53). The effect of the pandemic has been unprecedented and dramatic and changing almost every aspect of our lives overnight in more than a year until 2021. Over the past year, most educational institutions have implemented unprecedented changes to the home learning process, although implementation varies according to individual institution policies.

The widespread distribution of the Coronavirus in many countries has caused us to acknowledge that the climate is changing. We can see how Covid-19 affected technology, the economy, politics, and education during the crisis. Change necessitates that we are ready, answer with attitudes and behaviors, and continue to learn new things. One of the focuses, of all the areas that have become problems today, is on the educational side, which is critical for this discussion.

Indonesia is not alone in its search for alternatives that enable students to continue studying while also ensuring that their educational rights are respected. Indonesia faces significant difficulties in dealing with the Covid-19 pandemic. To keep Covid-19 from spreading, the pandemic forces a social as well as a physical separation scheme. As a result, this strategy is being followed to slow the pace of Coronavirus transmission in the population. The Ministry of Education and Culture responded by implementing an online learning policy that allows students to learn from home. Face-to-face learning is forced to be discontinued during the pandemic phase. Teachers and students who meet regularly must also learn online. The implementation of a physical distancing policy, which also becomes the foundation for introducing learning from home, with the use of information technology that appears out of nowhere, often surprises instructors, teachers, parents, and even everyone in the building. In Indonesia's education sector, information technology learning has been introduced in recent years. Online schooling, on the other hand, which arose as a result of the Covid-19 pandemic, stunned nearly all, from districts/cities to counties, centers, and even the international community.

Online learning has so far only existed as an idea, a technological instrument, rather than a way of thought or a learning model. Online learning is not a way to replace face-to-face learning with software apps, nor is it a way to overwhelm students with daily activities. Students should be encouraged to be innovative in their access to as many points of information as possible, deliver work, hone insights, and eventually turn themselves into lifelong learners by online learning. Online learning isn't just about transferring the face-to-face process to digital apps and assigning assignments. The science of educational technology creates powerful online learning platforms that take into account unique educational objectives. The ability to present difficult and rare information into the classroom is one of the concepts of using technology that must become a guide for students.

Educators or teachers must have the confidence to take action to make online learning an opportunity to change our education as a result of these challenges. Several moves, particularly in the area of online learning, can be viewed as a joint reflection on how to improve our educational system. To begin, all educators/teachers must be able to teach remotely, which, by the way, necessitates the use of technology. It is important to improve educators' ability to use distance learning technologies at all stages. Second, the application of technology is critical; there is a particular science that explains how technology should be used to achieve educational objectives. Lynch $(2012$, p. 1) states that technology is a tool that affects the way we work, play, and communicate. Technology changes our lives to decide how to use it or how to make it work.

E-learning or often referred to as online education (Electronic Learning or E-Learning) which also involves technology. It is typically developed by distance education, which does not include the conventional classroom environment, in which the teacher and students are educated at the same time and in the same place (Fitria, 2020). Online learning refers to learning and other supportive resources that are available through a computer (Carliner, 2004, p. 1). Stein \& Wanstreet (2017a) states that the more meaningful online learning is the greater quality of the learning experience and the overall satisfaction of the learners. According to Rajasingham \& Tiffin (2002, p. 19), the classroom facilitates such communication functions and how the educators/teachers use information technology to improve the classroom. 
Online learning is related to teaching students in the virtual classroom. To teach in the virtual classroom, educators/teachers must transition beyond what have been called traditional pedagogy styles, which mostly include lecturers, and into modern and more facilitative approaches. Teaching online entails far more than merely adapting tried-and-true pedagogical styles to a new format (Palloff \& Pratt, 2013). A virtual classroom is in form of a hybrid. In this case incorporating properties of two different delivery technologies between the face-to-face classroom and asynchronous e-learning (Clark \& Kwinn, 2007, p. 8). Lemov (2020, p. 15) states that the form of online learning consists of asynchronous and synchronous learning. Asynchronous happens when the work of learning occurs at different times and places. While synchronous happens at the same times but in a different place.

There are several technologies for online learning in the form of synchronous learning such as Google Classroom, Moodle, Edmodo, Schoology, Ed Link, or online video conferences such as Zoom, Skype, Google Hangouts Meet, Live YouTube, Self Platform, and other platforms. An English instructor must have the ability to teach English as well as optimize the teaching-learning process (Fitria, 2019). Those are several distance-learning began in March 2020, when COVID19 forced students and teachers around the world into virtual environments (Jump, 2020, p. 5).

Several previous studies related to the use of online e-learning platforms during the pandemic Covid-19. First, the use of Zoom Meeting which is written by Erito (2021), Firmansyah (2021), Haqien \& Rahman (2020), and Gunawan et al. (2021). Second, the use of Google Classroom which is written by Astuti \& Indriani (2020), Susanti \& Yany (2021), and Okmawati (2020). Third, the use of Google Meet which is written by Al-Maroof et al. (2020), Silviska \& Latifah, (2021), Wiratama (2020), Rozi et al. (2021), and Nasution \& Nandiyanto (2021). Fourth, the use of Microsoft Teams written by Wijayanto et al. (2021), Wea \& Kuki (2021), Saputra \& Saddhono (2021), Henderson et al. (2020) and Wahyuni \& Kusumawati (2021).

Based on the previous studies, video conferencing applications such as Zoom Meeting, Google Meet, and Microsoft Teams are some of the options that can be used to carry out teaching and learning activities. As time goes by, other applications for virtual meetings continue to appear, one of which is Gather Town, which is new and is a tight competitor to Zoom and Google Meet. Gather Town itself is simply a platform that combines video calls with 2D maps, allowing users to walk around and talk to other people. In appearance and content in it, old school video games with the 8-bit video quality. The Gather Town platform was developed by the company Gather Presence Inc. which was originally called Online Town at the time of its debut. Gather Town was created by three people, namely Kumail Jaffer, Phillip Wang, and Cyrus Tabrizi, then officially released on April 3, 2021. Based on this explanation, the researcher is interested to conduct research related to the 'Gather Town' platform video game-style for a virtual classroom. Therefore, the objective of this study is to simulate the use of the 'Gather Town' game platform as an alternative platform in creating a sensation of English Language Learning (ELL) in real classrooms through virtual class during the pandemic COVID-19.

\section{LITERATURE REVIEW}

\section{Virtual Classroom}

There are several definitions of a virtual classroom. Therefore, a virtual classroom is used to facilitate peer-to-peer meetings and discussions, social learning, a variety of training, and collaborative work on professional and academic projects (Montoute, 2013, p. 7). While, according to Corbett \& Huggett (2009, p. 1), the virtual classroom allows organizations or institutions to provide training or teaching at a lower cost because trainers, educators, and learners can stay at their desks to participate.

Concerning learning, a virtual classroom is a teaching and learning environment located within computer-mediated communication (Hiltz, 1994, p. 3). According to Christopher \& Hyder (2014, p. 4), virtual classroom combines elements of traditional face-to-face interaction of selfpaced e-learning with a reliable internet connection is need to connect learners in different places and times. The virtual classroom also condenses the number of time learners spends away from work because online sessions tend to have shorter durations than face-to-face classes. Most of the 
virtual classroom is available today in the learning (electronic learning) delivered through an electronic device such as a computer. Based on the definitions above, it can be concluded that Virtual classrooms are online classrooms or conference rooms available through an internet connection and a desktop or mobile computer.

\section{'Gather Town' Video Game}

The Gather Town platform was developed by the company Gather Presence Inc. which was originally called Online Town at the time of its debut. Gather Town was created by three people, namely Kumail Jaffer, Phillip Wang, and Cyrus Tabrizi, then officially released on April 3, 2021.

Gather Town itself is simply a platform that combines video calls with 2D maps, allowing users to walk around and talk to other people. In appearance and content in it, old school video games with the 8-bit video quality. Gather Town is a mingling tool that allows the users to speak with other conference attendees in groups or privately during the conference, especially throughout the breaks. It is accessed by a web browser (Chrome is recommended) which requires no installation or registration. When the users go to Gather Town, they must first enter the user name and choose an avatar before the user can begin.

If the virtual room in Zoom is called Room, in Gather Town it is called Space. This virtual space or space will be in the form of a 2D map with an 8-bit display. There are various folders, ranging from home situations, meeting rooms, classrooms, parks, halls, and many more. Users can also make their folders with creative ideas. Apart from the map, Space also displays participant video calls in small boxes at the top of the screen. Users can turn off or turn on the camera and microphone. In addition, there is a chat tab at the bottom left corner of the screen where the users can chat with all participants or the users can chat privately. All Gather Town users can also share documents via Google Docs to collaborate on assignments or jobs. In addition, the users can insert YouTube and Twitch video links that can be watched together.

Gather Town itself is an online application that can be used to make online meetings more fun and interesting. Gather Town itself can be used for free and can be customized for free, unfortunately, this application can only accommodate 25 people, and for the rest, there will be a price to pay to use it. Gather Town charges an additional fee of US \$ 1 per user for the Town package. Meanwhile, 2 US dollars per user for the City package and 3 US dollars for the Metropolis package. The difference between each package lies in the area of space or virtual space provided, as well as more and more additional objects that can be used. As at a real-world conference or other meetings, the users can easily start and end side conversations and chats, or return to the main speaker. Rather than being ushered into a Zoom meeting space, we can simply walk the user's online self to tables and chairs, sit down, and begin a discussion in Gather Town.

Gather Town has some pre-built virtual environments targeted at educators - there is a prebuilt classroom setting, a generic campus setting, a dorm, a quad, a lab. There are also virtual representations of the MIT and Carnegie Mellon campuses, specifically, or the users can create the user's own. Within the users' environment, Gather Town allows the users to add virtual components and tools to the users' virtual space, such as a whiteboard, a podium, or a specific video stream, to more fully mimic a classroom or conference setting.

The users can try Gather Town for free. For free users, they can 1) open the site https://gather.town/. 2) Select "Launch Gather" to start the virtual meeting, 3) select "Create new space". Then a page will appear to fill in the space name that the users created and the password. 4) Select a map that is already available. Next, the users will be asked to create an avatar in 8-bit lines. 5) Fill in the name and choose the style of hair and costume used. 6) Check the camera, microphone, and speakers to make sure they are working then, press "Join the Gathering". The users are already in a virtual room like an old-school video game. 7) To invite friends, press the "Participant" option and select "Invite". Copy the link and share it with the users' friends or colleagues.

\section{RESEARCH METHOD}


This research is descriptive qualitative. This type of qualitative descriptive research is a research method that utilizes qualitative data and is described descriptively. It displays the results of the data as they are without any manipulation or other treatment processes. The purpose of this research is to produce a picture of an object and describe the mechanism of a process, provides a complete picture in a verbal or numerical form about the "Gather Town" platform video gamestyle for a virtual classroom.

The collecting method used observation. Observation is an activity done to process an object to feel and then to understand the knowledge of a phenomenon based on known knowledge and ideas, to obtain the necessary information to proceed with an investigation. In this research, the researcher observed the simulation of the 'Gather Town' platform video game-style for virtual classrooms. Besides observation, the researcher also uses in-depth interviews. In this way, researchers no longer ask respondents to read questionnaires and provide answer choices but send interviewers to ask questions orally and record answers given by respondents. In this research, the research interview a respondent as a student who asked to join the virtual classroom by using Gather Town. An interview is done by phone after the simulation of the virtual classroom to know his perception toward the use of Gather Town in creating a virtual classroom.

The analyzing method used several steps of qualitative, are reducing data displaying data, and making a conclusion. Reducing data means summarizing, choosing the main things, focusing on the important things, looking for patterns and themes, and removing unnecessary. After the data is reduced, the next step is to display the data in the form of brief descriptions, charts, relationships between categories, flowcharts, and the like. The third step is drawing conclusions related to the results of data analysis.

\section{FINDINGS AND DISCUSSION}

\section{Findings}

\section{The Use of 'Gather Town' for Simulation an English Virtual Classroom}

The plus point of Gather Town is that it doesn't feel like a virtual meeting in general. Gather Town users will be invited to play games when conducting virtual meetings. The room in Gather Town is called Space. This space will be in the form of a 2D map with an 8-bit display. There are several folders that you can use for virtual meeting purposes, such as homes, meeting rooms, classes, parks, halls, and several others. Users can also create their maps. The simulation of using Gather Town for English Virtual Classroom can be described in the following pictures below:

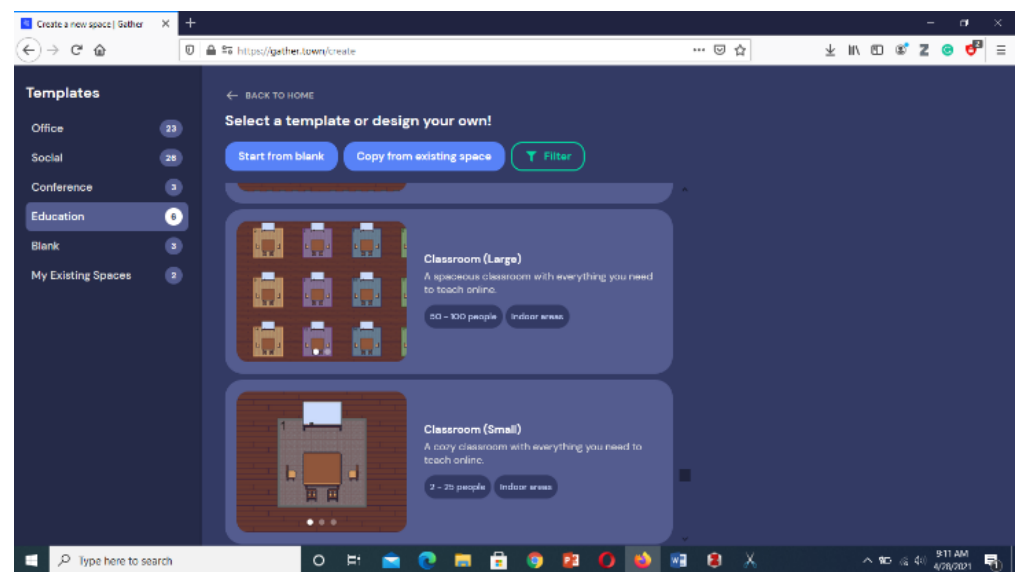

Picture 1. Templates in Gather Town

Picture 1 shows that there are several templates of Gather Town. If the virtual room in Zoom is called Room, in Gather Town it is called Space. This virtual space or space will be in the form of a 2D map with an 8-bit display. There are various templates, ranging from office, social, conference, education, work, home situations, and my existing places. 1) In-office Space consists 
of 23 Space, they are Tiny, Small, Medium and Large, 2) In social consist of Family Gathering (Cozy), Family Gathering (Cute), Castle, Coffee Shop, Diner (Medium), Diner (Small), Game Room (Large), Game Room (Medium), Game Room (Small), Living Room, Lounge (Large), Lounge (Small), Moonpond, Outdoor Keynote, Park (Daytime), Park (Nighttime), Rooftop Party, Space Station, Study, Waterfront Gathering. 3) In conference Space consist of Basic Conference, Deluxe Conference, and Standalone Keynote. 4) In education, consist of Auditorium for 100+ people, Classroom (large) for 50 - 100 people, Classroom (Small) for 2 - 25 people, Recess for $100+$ people, School (Medium) for 100+ people, School (Small) for 50 - 100 people. 5) Blank consists of an Empty Room (Medium) for 25 - 50 people, and Empty Room (Small) for 2-25 people. 6) My existing places. Here, the users can also make their templates with creative ideas.

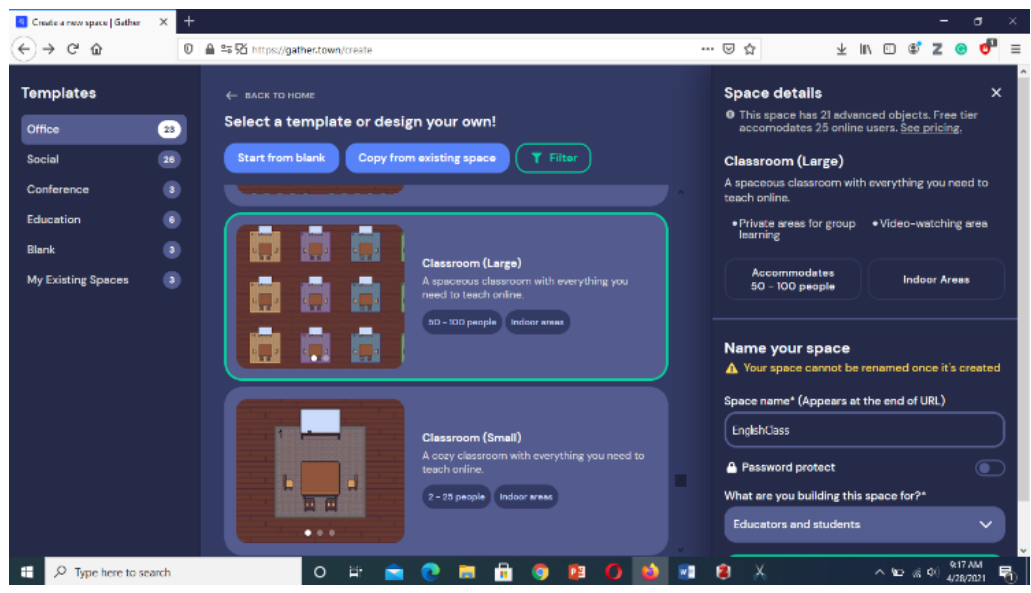

Picture 2. Choosing Classroom template in Gather Town

Picture 2 shows that an English lecturer/teacher can choose a template, for example, Classroom. Here, an English lecturer/teacher chooses Classroom (Large) is a spacious classroom with everything the lecturers/teachers need to teach online. This Space can accommodate $50-100$ people (students) in indoor areas. On the right side, the lecturers/teachers can write a Space name (class), for example, English class. The English lecturer/teacher also can fill the answer "What are you building this space for?". The English lecturer/teacher can choose "Educators and students", then create a space.

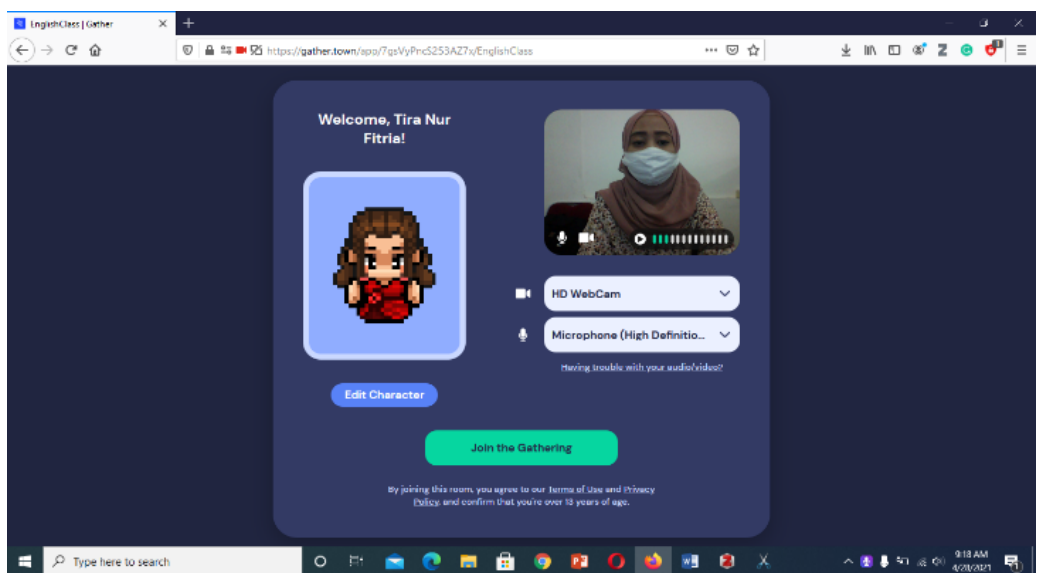

Picture 3. Creating a Classroom space in Gather Town

Picture 3 shows that after the lecturer creates a space. The next step is to decide which avatar of the lecturers/teachers want to use. The lecturers/teachers can edit characters by choosing their 
hairstyle and costume that the users want to use. This avatar appears in an 8-bit line. The lecturers/teachers also have to check first, whether the camera, microphone and speakers are functioning properly. Then, they can immediately press 'Join the Gathering'.

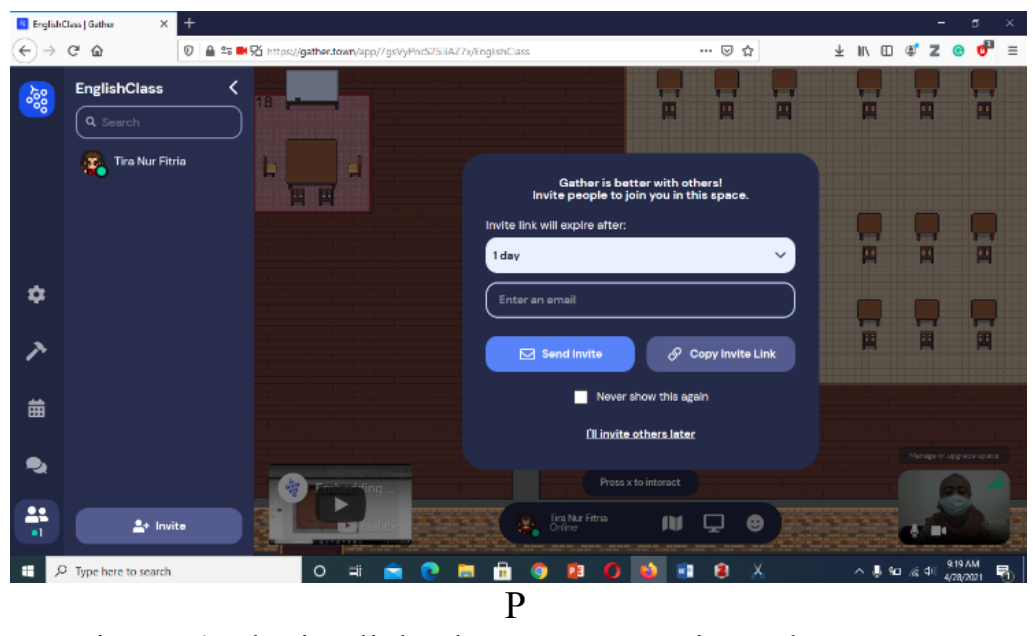

icture 4. Sharing link Classroom space in Gather Town

Picture 4 shows that the lecturers/teachers will immediately enter a virtual classroom with a video game-style display. To invite students to join, the lecturers/teachers can press the option "Participant" then select "Invite". Then copy the link and share it with students who want to be invited to join the virtual classroom (English class) in the link https://gather.town/i/F3O0fD99. The students do not need to have an account, register or login into Gather Town. They can join directly into virtual class (English Class) by clicking the link given from their computer, tablet, laptop, or their phone.

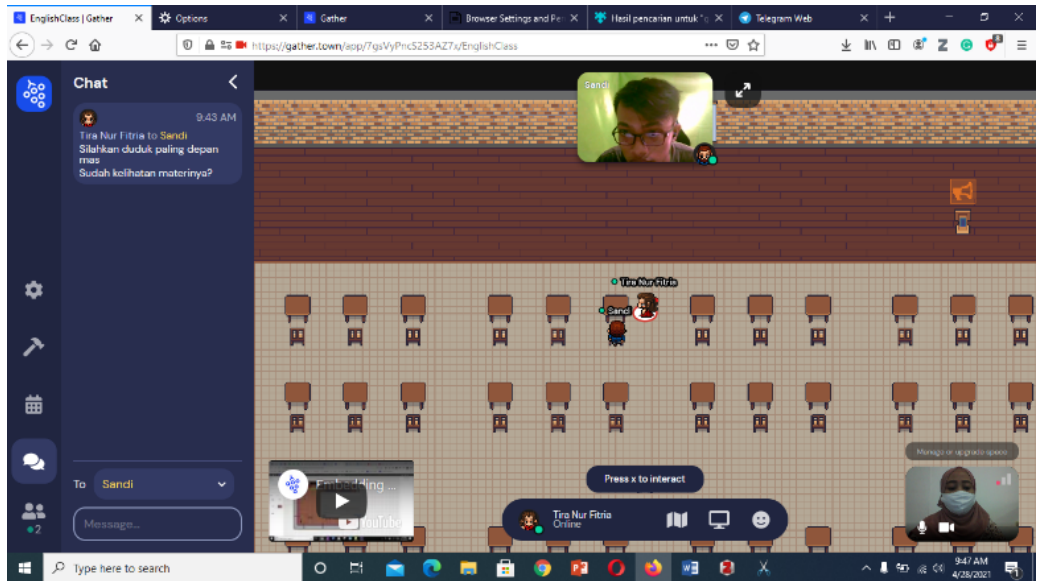

Picture 5. The View of Classroom space in Gather Town

Picture 5 shows that the lecturers/teachers are in the Classroom space. Not only that, but even users can show their creative ideas to make the map they want. In addition to the map display, the faces of the people involved in this virtual meeting are also displayed in small boxes on the screen. Like Zoom and Google Meet, in Gather Town this virtual meeting application the users can also choose whether the users want to turn on or turn off the camera and microphone or not. Another option in the chat feature, the users can use the chat tab at the bottom left corner of the screen to chat with all meeting participants or if the users want to have a private meeting. The room is designed similar to a classroom, where the lecturer's desk is at the front of the classroom. The 
virtual classroom also has chairs that are lined up neatly like classrooms in the real world. Then when doing group assignments, the student characters will gather at the same table.

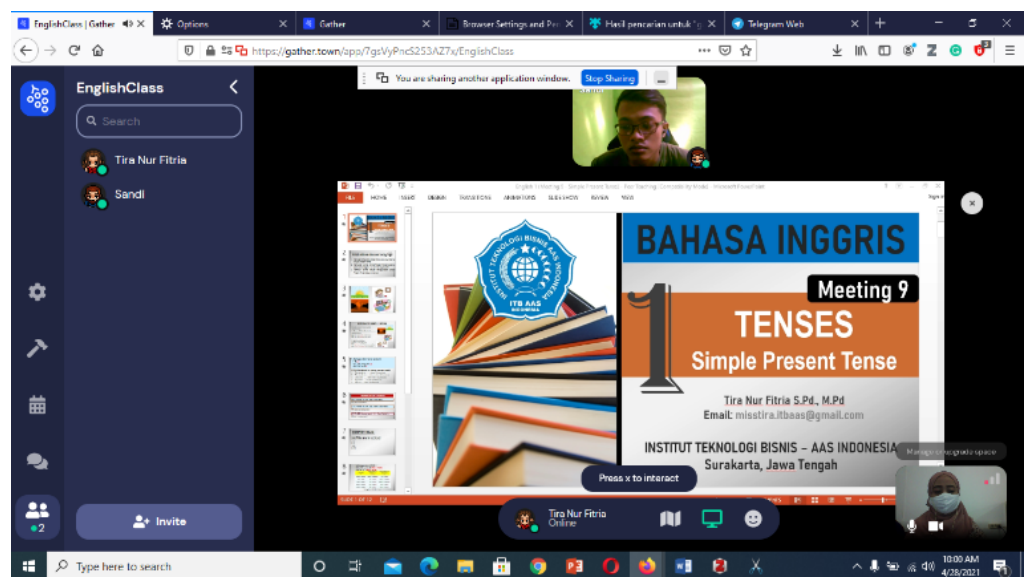

Picture 6. The View of Share Screen in Classroom space in Gather Town

Picture 6 shows that the lecturer can share a screen with all of the students they are connected to on Gather Town. To do so, the lecturer can click on the Screen Sharing icon in the center Control Bar at the bottom of her/his screen. Then, the screen will automatically appear on the students' screen, then the teaching and learning process can be done es as usual like other virtual meetings.

\section{Discussion}

Virtual meetings have now become a common thing to do during the corona pandemic. From time to time, applications for virtual meetings keep popping up, one of which is Gather Town, which is now being used and has become a tight competitor to Zoom and Google Meet. Gather Town itself is simply a platform that combines video calls with 2D maps, allowing users to walk around and talk to other people. In terms of appearance and content, it is an old-school video game with the 8-bit video quality.

During the COVID 19 pandemic, learning that generally has to be used between teachers and students must be done online. Although useful, it is not very effective, quite a lot of people feel bored with this activity, various applications and creative ideas are used by teachers to increase the attention of their students. This strategy can also be used by lecturers in university and school environments, where teachers/lecturers can mimic classroom desks and whiteboards. Gather Town, a platform that combines video calls with 2D maps and allows users to walk around and talk to other users. In appearance, the platform looks like an old video game with the 8-bit video quality. Using Gather Town, users seem to be playing games while conducting virtual meetings so it's not so boring. Based on the findings above, this is also supported by the interview result of a student related to Gather Town.

$1^{\text {st }}$ question

Lecturer: What platforms have lecturers used to teach English courses during this pandemic? (Platform apa yang biasa digunakan dosen dalam mengajar perkuliahan Bahasa Inggris selama pandemi ini?).

Student: During this pandemic, lecturers in teaching English used several types of platforms, such as Zoom, Google Meet and YouTube Live Streaming. Lecturers also use Google Classroom (Selama pandemi ini, dosen dalam mengajarkan Bahasa Inggris menggunakan beberapa jenis platform, seperti Zoom, Google Meet dan Live Streaming Youtube. Dosen juga pakai Google Classroom). 
Based on the $1^{\text {st }}$ answer of an interview, due to the emergence of the COVID-19 virus that has hit our country and even throughout the world, so that all activities during this pandemic are carried out online such as in Institute Technology Business AAS Indonesia. The English lecturer usually teaches students online by using several e-learning platforms. Though student experiences are still virtual, students experience online learning by Zoom, Google Meet, Live Streaming YouTube, or Google Classroom.

\section{Question 2.}

Teacher: Have you heard of the Gather Town app before? (Apa Anda pernah mendengar tentang aplikasi Gather Town sebelumnya?)

Student: Previously I had never heard of this application, but when I saw the appearance of Gather Town, this application is like an application in a game, there are several Avatar characters that can be involved in this game (Sebelumnya saya belum pernah mendengar aplikasi ini, tapi ketika saya melihat tampilan Gather Town ini, aplikasi ini seperti aplikasi dalam permainan game, ada beberapa tokoh Avatar yang dapat dlibatkan didalam game ini).

Based on the $2^{\text {nd }}$ answer of an interview, Gather Town itself is a new platform officially released on April 3, 2021. It is simply a platform that combines video calls with 2D maps, allowing users to walk around and talk to other people. In appearance and content in it, old school video games with the 8-bit video quality. The Gather Town platform was developed by the company Gather Presence Inc. which was originally called Online Town at the time of its debut. Apart from zooming, there is another virtual meeting application that is even more exciting, like playing the Harvest Moon game called Gather Town. Gather Town is web conferencing software like Zoom, but with an added component to see the virtual "room" the users and other people are in.

\section{Question 3.}

Teacher: Are you having trouble when you want to join a class (space) in Gather Town? (Apakah Anda mengalami kesulitan saat ingin join kelas (space) dalam Gather Town?)

Student: I have no difficulty, because I just joined me directly by using the link shared on the Whatsapp group. I don't need to register for a Gather Town account, and can immediately attend the class (Saya tidak mengalami kesulitan, karena saya hanya langung join saya dengan menggunakan link yang dishare di grup Whatsapp. Saya tidak perlu mendaftar akun Gather Town, dan bisa langsung hadir didalam kelasnya).

Based on the $3^{\text {rd }}$ answer of an interview, it supports picture 4 above. In Gather Town, the lecturer invites students to join the space/class. The lecturer can press the option "Participant" then select "Invite". Then copy the link and share it with students who want to be invited to join the virtual classroom. In joining the class/space of Gather Town, the students do not need to have an account, register or login into Gather Town. They can join directly into virtual class by clicking the link given from their computer, tablet, laptop, or their phone.

Question 4.

Teacher: In your opinion, how will the class/space look in Gather Town? (Menurut Anda, bagaimana tampilan kelas/space di Gather Town?)

Student: This application is like a video game, but there are several options for space to choose from. When I joined this class, it looks like a class. There are many student chairs and lecturers' desks in front of it. There is a blackboard too. (Aplikasi ini seperti video game, tapi ada beberapa pilihan ruang yang bisa dipilih. Pas saya ikut gabung kelas ini, tampilannya seperti didalam kelas. Ada banyak kursi-kursi siswa dan meja dosen didepannya. Ada papan tulis juga). 


\section{Question 5.}

In your opinion, when you were in Gather Town's virtual classroom, did you feel like you were in a real classroom? (Menurut Anda, ketika didalam kelas virtual Gather Town, apakah Anda merasa seperti didalam kelas nyata?)

Yes, I was like a real classroom. It's been a long time since I went to college, didn't sit in the classroom during this pandemic, so I want to go back to college and learn in class. But through Gather Town, it is like an online class. I can choose my own seat like in the classroom. (Ya, saya seperti diruang kelas nyata. Sudah lama tidak masuk kuliah, tidak duduk diruang kelas selama pandemi ini, saya jadi ingin kembali masuk kuliah dan belaajr didalam kelas. Tapi lewat Gather Town ini, membuat seperti kelas online. Sayabisa memilih tempat duduk sendiri seperti didalam kelas).

Based on the $4^{\text {th }}$ and $5^{\text {th }}$ answers of an interview, it supports picture 5 above. Apart from that, the users also can move and interact with other participants based on the location in the room, just like a real class. Users of Gather Town may use augmented reality to incorporate elements of their work. Gather Town incorporates features from common interactive meeting platforms like Zoom and Google Docs to create virtual chatrooms that look and feel like real-life classrooms. There are several maps to choose from, such as home situations, meeting rooms, classrooms, parks, halls, and many more. Users can also build their own space as desired. The platform has graphics similar to the Harvest Moon game, where students can play a single character and can write their name on the top so that the lecturer can see which students are present or not. Not only that, but the class also has similar graphics. The room is designed similar to a classroom, where the lecturer's desk is at the front of the classroom. The virtual classroom also has chairs that are neatly lined up like classrooms in the real world. Then when doing group assignments, the student characters will gather at the same table.

Question 6.

Teacher: In your opinion, how is the Gather Town application different from other platforms for teaching online such as Zoom?. (Menurut Anda, apa perbedaan aplikasi Gather Town ini dengan platform lainnya dalam mengajar online seperti Zoom?)

Student: For Gather Town, I don't need to create an account, so I don't click on the link, I can immediately join the class. But when I join a class using Zoom, I have to register an account first, then I sometimes have to enter a password first before I can join the class. In appearance, it is actually the same as Zoom, when the lecturer screens the material sharing, I can see the material on my screen). (Kalau Gather Town, saya tidak perlu membuat akun, jadi tingak klik linknya, saya bisa langsung join kelas. Tapi kalua pas saya ikut kelas dengan menggunakan Zoom, saya harus daftar akun dulu, terus saya kadnag harus masukin password dulu baru bisa join kelas. Secara tampilan, sebenanya juga sama seperti Zoom, ketika dosen screen sharing materi, saya dapat melihat materi tersebut dilayar saya).

There are several advantages of Gather Town compared to Zoom and Google Meet is that it is positioned as a platform that is not only used for virtual meetings. Gather Town users will be invited as if they were playing a game during a virtual meeting. Gather Town is a webconferencing program similar to Zoom, but with the added feature of being able to see the virtual "home" the users and others are in, as well as switch around and communicate with other participants depending on where the users are in the room, much like in real life.

In contrast to attending scheduled Zoom sessions, student-teacher interactions in Gather Town can be more casual since avatars can freely wander around the building and enter various classrooms. The students can join and leave small discussion groups more quickly than Zoom breakout rooms by simply guiding their avatars to walk away from a group as they would in a typical in-person encounter. 
But, Gather Town also has weaknesses. To be able to use Gather Town the users can join for free. However, there are several provisions. Among them, for free, it can be used with a maximum of 25 participants with a time limit of 2 hours. Apart from these limitations, free users also cannot use the map construction feature itself. Even so, free users can still add attributes or items to the map. Gather Town can be used for free with several conditions. Free accounts can be used for a maximum of 25 participants and a time limit of 2 hours. Apart from that limitation, free account users cannot build or customize their maps. However, free Gather Town users are still allowed to add attributes or items to the map. Like adding office furniture, homes, to game items. There are various kinds of games provided, ranging from Tetris, Poker, Sudoku, and others.

Question 7.

Teacher: In your opinion, can the Gather Town platform be used as an alternative for further English learning? (Menurut Anda, apakah platform Gather Town ini dapat digunakan sebagai salah satu alternative pembembelajaran Bahasa Inggris selanjutnya?)

Student: Yes. Sometimes online lectures using Zoom, Google Classroom, or YouTube make me bored. So in class with Gather Town it feels like I'm studying in a classroom with a display model like I'm playing a video game. (Ya. Kadang perkuliahan online menggunakan Zoom, Google Classroom, atau YouTube membuat saya bosan. Jadi kalau perkuliahan dengan Gather Town berasa seperti saya sedang belajar diruang kelas dengan model tampilan seperti sedang memainkan video game).

Several video conference applications such as Zoom, Google Classroom, and Google Meet are the main choices for teaching and learning activities. However, this method often becomes boring for students. Video conferencing applications such as Zoom Meeting, Google Meet, and Microsoft Teams are some of the options that can be used to carry out teaching and learning activities. However, this method often becomes the main option for students/learners. But, educators/teachers can choose to do their learning by using other alternative online learning platforms such as by using video game platforms like Gather Town.

A virtual class is a class created with the help of the internet. In this class, all learning activities are carried out online using the internet. The learning process is carried out without requiring participants to be present in a real classroom. Through virtual classes, students can take part in learning in their respective places that are connected to the internet, for example at home, at work, or at schools and campuses. Learning material content, question and answer, discussion, communication, video streaming, monitoring of learning activities, learning outcomes, and displaying the results of tests can be done in a virtual classroom. So in a virtual classroom can facilitate learning like a physical class. In a virtual classroom, students can also interact with other students, participants with educators, and students with learning content that has been provided by educators, in this case, teachers and lecturers.

Apart from using various e-learning platforms, there is another virtual meeting application that is even more exciting, like playing the Harvest Moon game named Gather Town. Virtual classes are virtual but can function like physical classes, such as the use of a game-based application called Gather Town. Gather Town is web conferencing software like Zoom, Webex, or Google Meet, but with an added component to view the virtual "rooms" where faculty and students are located. In addition, you also can move and interact with other students based on the location in the room, such as in a real class or virtual classroom.

\section{CONCLUSION AND SUGGESTION}

\section{Conclusion}


Besides several virtual meeting application that is even more exciting, like playing the Harvest Moon game called Gather Town. Gather Town is web conferencing software like Zoom, but with an added component to see the virtual "room" the users and other people are in. Apart from that, the users also can move and interact with other participants based on the location in the room, just like a real class. Users of Gather Town may use augmented reality to incorporate elements of their work. Gather Town incorporates features from common interactive meeting platforms like Zoom. Gather Town has graphics students can play one character and can write their name on the top so that the lecturer can see which students are present The class also has similar graphics. The room is designed similar to a classroom, where the lecturer's desk is at the front of the classroom. The virtual classroom also has chairs that are neatly lined up like classrooms in the real world. Then when doing group assignments, the student characters will gather at the same table as in a real classroom. Gather Town has several virtual environments targeted at educators in online teaching. In it, there are classroom arrangements and many more according to what educators make. Uniquely, Gather Town allows lecturers to add virtual components and tools to spaces such as whiteboards, podiums, or video streams like virtual classrooms.

\section{Suggestion}

Many video conferencing applications such as Zoom Meeting, Google Meet, YouTube, Google Classroom. and Microsoft Teams are some of the options that can be used to carry out teaching and learning activities. However, this method often becomes the main option for students/learners. But, educators/teachers can choose to do their learning by using other alternative online learning platforms such as by using video game platforms like Gather Town. Lectures can still run online as long as there is cooperation and discipline from lecturers and students. However, online lectures are something that must be done because they are part of government policy and are done to reduce the risk of spreading Coronavirus Disease (Covid-19).

\section{REFERENCES}

Al-Maroof, R. S., Salloum, S. A., Hassanien, A. E., \& Shaalan, K. (2020). Fear from COVID-19 and technology adoption: The impact of Google Meet during Coronavirus pandemic. Interactive Learning Environments. https://www.tandfonline.com/doi/abs/10.1080/10494820.2020.1830121

Astuti, T., \& Indriani, L. (2020). The EFL Students' Perceptions in Using Google Classroom for English Learning During Pandemic. Jurnal Review Pendidikan dan Pengajaran, 3(2), 328335.

Bergan, S., Gallagher, T., Munck, R., \& Land, H. Van't. (2021). Higher education's response to the Covid-19 pandemic: Building a more sustainable and democratic future. Council of Europe.

Carliner, S. (2004). An Overview of Online Learning. Human Resource Development.

Christopher, D., \& Hyder, K. (2014). The Successful Virtual Classroom: How to Design and Facilitate Interactive and Engaging Live Online Learning. AMACOM.

Clark, R. C., \& Kwinn, A. (2007). The New Virtual Classroom: Evidence-based Guidelines for Synchronous e-Learning. John Wiley \& Sons.

Corbett, W. G., \& Huggett, C. (2009). Designing for the Virtual Classroom. American Society for Training and Development.

Erito, S. N. P. (2021). Postgraduate Students' Experiences on the Use of Zoom Meeting in Online Lecture During Pandemic. NATIONAL SEMINAR OF PBI (English Language Education), $151-158$.

Firmansyah, F. (2021). Efektivitas Penggunaan Aplikasi Zoom Sebagai Media Pembelajaran Online masa Pandemi Covid-19 pada Mahasiswa STAI Al-Amin Dompu. AL-FURQAN, 9(2), 11-18.

Fitria, T. N. (2019). Teaching English to the University Students by Using a Wall Magazine as Media as a Project Based Learning. JET ADI BUANA, 4(1), 13-23. 
https://doi.org/10.36456/jet.v4.n1.2019.1881

Fitria, T. N. (2020). Teaching English through Online Learning System during Covid-19 Pandemic. Pedagogy: Journal of English Language Teaching, 8(2), 138-148. https://doi.org/10.32332/pedagogy.v8i2.2266

Gunawan, G., Kristiawan, M., Risdianto, E., \& Monicha, R. E. (2021). Application of the Zoom Meeting Application in Online Learning During the Pandemic (SSRN Scholarly Paper ID 3819839). Social Science Research Network. https://papers.ssrn.com/abstract=3819839

Haqien, D., \& Rahman, A. A. (2020). Pemanfaatan Zoom Meeting untuk Proses Pembelajaran pada Masa Pandemi Covid-19. SAP (Susunan Artikel Pendidikan), 5(1), Article 1. https://doi.org/10.30998/sap.v5i1.6511

Henderson, D., Woodcock, H., Mehta, J., Khan, N., Shivji, V., Richardson, C., Aya, H., Ziser, S., Pollara, G., \& Burns, A. (2020). Keep calm and carry on learning: Using Microsoft Teams to deliver a medical education program during the COVID-19 pandemic. Future Healthcare Journal, 7(3), e67. https://doi.org/10.7861/fhj.2020-0071

Hiltz, S. R. (1994). The Virtual Classroom: Learning Without Limits Via Computer Networks. Intellect Books.

Jump, J. (2020). 50 Strategies for The users' Virtual Classroom ebook. Teacher Created Materials.

Lemov, D. (2020). Teaching in the Online Classroom: Surviving and Thriving in the New Normal. John Wiley \& Sons.

Lynch, M. M. (2012). Learning Online: A Guide to Success in the Virtual Classroom. Routledge.

Montoute, R. (2013). 16 Essential Tips For Planning To Moderate A Virtual Classroom Event. Rosanna Montoute.

Nasution, A. R., \& Nandiyanto, A. B. D. (2021). Utilization of the Google Meet and Quiziz Applications in the Assistance and Strengthening Process of Online Learning during the COVID-19 Pandemic. Indonesian Journal of Educational Research and Technology, 1(1), $31-34$.

Okmawati, M. (2020). The Use of Google Classroom during Pandemic. Journal of English Language Teaching, 9(2), 438-443. https://doi.org/10.24036/jelt.v9i2.109293

Palloff, R. M., \& Pratt, K. (2013). Lessons from the Virtual Classroom: The Realities of Online Teaching. John Wiley \& Sons.

Rajasingham, L., \& Tiffin, J. (2002). In Search of the Virtual Class: Education in an Information Society. Routledge.

Rozi, A. F., Amaniyah, I., Rahmawati, I., \& Lailiyah, S. (2021). As Efektivitas Pembelajaran Daring Menggunakan Google Meet dan Whatsapp Group untuk Meningkatkan Hasil Belajar Matematika Selama Pandemi Covid 19. MODELING: Jurnal Program Studi PGMI, 8(1), 28-42. https://doi.org/10.36835/modeling.v8i1.717

Saputra, A. D., \& Saddhono, K. (2021). Pembelajaran Bahasa Indonesia Menggunakan Microsoft Office Team 365 untuk SMA di Masa Pandemi. LINGUA: Jurnal Bahasa, Sastra, Dan Pengajarannya, 18(1), 16-26. https://doi.org/10.30957/lingua.v18i1.669

Silviska, I. A., \& Latifah, D. (2021). Google Meet as Learning Media for Vocal Techniques During the Covid-19 Pandemic. 281-283. https://doi.org/10.2991/assehr.k.210203.060

Stein, D. S., \& Wanstreet, C. E. (2017a). Jump-Start The users' Online Classroom: Mastering Five Challenges in Five Days. Stylus Publishing, LLC.

Stein, D. S., \& Wanstreet, C. E. (2017b). Jump-Start The users' Online Classroom: Mastering Five Challenges in Five Days. Stylus Publishing, LLC.

Susanti, D., \& Yany, N. F. (2021). Understanding the use Of Google Classroom for Teachers During the Pandemic Covid-19 COVID-19. JCES (Journal of Character Education Society), 4(2), 484-494. https://doi.org/10.31764/jces.v4i2.4261

Wahyuni, P., \& Kusumawati, M. (2021). The Use of Microsoft Office 365 In Mathematics Learning During The COVID-19 Pandemic. Proceeding International Conference on Science and Engineering, 4, 162-165.

Wea, K. N., \& Kuki, A. D. (2021). Students' Perceptions of Using Microsoft Teams Application in Online Learning During the Covid-19 Pandemic. Journal of Physics: Conference Series, 
1842(1), 012016. https://doi.org/10.1088/1742-6596/1842/1/012016

Wijayanto, Y. R., Andayani, A., \& Sumarwati, S. (2021). Utilization of Microsoft Teams 365 as an Alternative for Distance Learning Media Amid the Covid-19 Pandemic. International Journal of Multicultural and Multireligious Understanding, 8(2), 87-93. https://doi.org/10.18415/ijmmu.v8i2.2333

Wiratama, N. A. (2020). Penerapan Google Meet dalam Perkuliahan Daring Mahasiswa PGSD Pada Mata Kuliah PKN Saat Pandemi Covid-19. JTIEE (Journal of Teaching in Elementary Education), 4(2), 1-8. https://doi.org/10.30587/jtiee.v4i2.2152 